\title{
Penguatan Kelompok, Koperasi Dan Kewirausahaan Pada Peternak Sapi Pasundan Di Kabupaten Kuningan
}

\section{Strengthening Groups, Cooperatives and Entrepreneurship in Pasundan Cattle Breeders in Kuningan Regency}

\author{
Munandar Sulaeman ${ }^{1}$, Marina Sulistyati ${ }^{1}$, Linda Herlina ${ }^{1}$, Anita Fitriani ${ }^{1}$, Unang \\ Yunasaf ${ }^{1}$, Hermawan ${ }^{1}$ \\ ${ }^{1}$ Fakultas Peternakan Universitas Padjadjaran \\ Jl Raya Bandung Sumedang Km 21 Jatinangor Sumedang 45363 \\ aemail: marina.sulistyati@unpad.ac.id
}

\begin{abstract}
Abstrak
Kegiatan ini bertujuan untuk memberikan pengetahuan dan wawasan mengenai penguatan kelompok, koperasi dan kewirausahaan dalam rangka peningkatan pendapatan khususnya bagi peternak sapi Pasundan di kabupaten Kuningan. Permasalahan yang muncul adalah belum optimalnya pemahaman peternak mengenai peran kelompok, permintaan akan pendirian koperasi dan peluang meningkatkan usaha sapi Pasundan menjadi usaha mencirikan kewirausahaan.Pendekatan formal dan informal digunakan dalam pelatihan agar materi dapat diterima dengan mudah oleh peserta. Pelatihan dan penyuluhan dilakukan melalui tahapan: observasi awal, diskusi mengenai permasalahan dan solusi, pemaparan, serta evaluasi, namun terkait dengan pandemi covid maka materi disampaikan dalam bentuk video yang diunggah pada aplikasi youtube. Kegiatan dilaksanakan pada Kelompok Ciciap dan Jaksataruna di Kecamatan Cibingbin Kabupaten Kuningan. Jumlah Peserta yang diundang dalam kegiatan sebagai tokoh penyebar video materi PKM adalah sebanyak 20 orang. Kesimpulan dari pelaksanaan kegiatan ini adalah terjadi peningkatan pengetahuan peternak mengenai penguatan kelompok, koperasi, dan kewirausahaan. Selain itu, peternak, terutama ketua kelompok memberikan respon positif terhadap rencana pembentukan koperasi di wilayahnya. Strategi para peternak selanjutnya adalah merencanakan pendirian koperasi dari dua kelompok tersebut.
\end{abstract}

Kata kunci: Sapi Pasundan, Kelompok Peternak, Koperasi, Kewirausahaan

\begin{abstract}
This activity aims to provide knowledge and insights about strengthening groups, cooperatives and entrepreneurship, especially for Pasundan cattle breeders in Kuningan district. The problems that arise are that the breeders' understanding of the role of the group is not optimal, the demand for the establishment of a cooperative and the opportunity to increase the Pasundan cattle business into an entrepreneurial characterization effort. Formal and informal approaches are used in training so that the material can be accepted easily by participants Training and counseling are carried out in stages: initial observation, discussion of problems and solutions, exposure, and evaluation, but related to the Covid pandemic, the material is delivered in the form of a video uploaded on the YouTube application. The number of participants who were invited to participate in the activities as the disseminators of PKM material videos was 20 people. The conclusion from the implementation of this activity is that there is an increase in breeders' knowledge about strengthening groups, cooperatives, and entrepreneurship. In addition, breeders, especially group leaders, gave a positive response to the plan to form cooperatives in their area. The next strategy for breeders is to plan the establishment of a cooperative from the two groups.
\end{abstract}

Keywords: Pasundan Cattle, Farmer Group, Cooperative, Entrepreneurship 


\section{Pendahuluan}

Peternakan rakyat skala kecil merupakan family business yang dioperasikan oleh anggota keluarga. Rutinitas kegiatan dalam usahaternak relatif teratur dan telah dikuasai oleh peternak, namun kegiatan usaha di hulu merupakan sebagian dari usaha agribisnis secara keseluruhan. Agribisnis terdiri dari beberapa subsistem yaitu subsistem penyediaan input produksi, subsistem budidaya, subsistem pengolahan produk hasil ternak, subsistem pemasaran, dan lembaga penunjang seperti pemerintah, akademik, dan lembaga penyedia sumber dana. Beberapa review penelitian pemasaran menunjukkan bahwa perbandingan antara share peternak dengan resiko usaha dalam pemasaran produk peternakan baik dalam bentuk raw material maupun produk olahan hasil ternak lebih kecil daripada share pedagang ternak dan atau olahannya. Hal ini berarti usaha agribisnis pada bagian hilir memberikan tawaran usaha yang memberikan keuntungan relatif besar.

Usaha ternak sapi Pasundan sampai saat ini memberikan potensi yang tinggi untuk dikembangkan, mengingat permintaan akan daging semakin meningkat sejalan dengan peningkatan pendidikan, pendapatan dan kebutuhan masyarakat. Usaha peternakan sapi Pasundan di Kabupaten Kuningan sebagian besar didominasi oleh peternakan rakyat yang masih bersifat subsisten. Meskipun dengan kondisi terbatas, usaha ternak sapi Pasundan memiliki arti yang sangat besar bagi peternak.

Keberadaan kelompok peternak sapi Pasundan di Kabupaten Kuningan merupakan upaya peternak untuk meningatkan kemampuan peternak secara berjamaah sehingga dapat meningkatkan pendapatan keluarga. Kondisi di lapangan menunjukkan bahwa keberadaan kelompok hanya sebagai tempat silaturachmi belum optimal dimanfaatkan, sehingga diperlukan upaya untuk meningkatkan melalui penguatan kelompok (Wardani dan Oeng Anwarudin, 2018).

Peran kelompok sebagai wadah antar peternak ataupun antar kelompok dalam mengembangkan usahataninya perlu didukung oleh lembaga yang secara formal dapat memfasilitasi aktivitas peternak yaitu melalui "koperasi". Hal ini sejalan dengan harapan Dinas Peternakan Kabupaten Kuningan kepada tim dosen untuk memberikan pemahaman kepada peternak mengenai pendirian koperasi peternak sapi Pasundan di Desa Bantar Panjang. Sampai saat ini limbah dari sapi Pasundan belum dimanfaatkan, melalui upaya kewirausahaan dapat meningkatkan nilai tambah jika dikelola menjadi produk yang memiliki nilai, seperti menjadi kompos dan vemicompos.

Produk hasil ternak bervariasi tergantung pada jenis dan manfaat produk tersebut bagi kebutuhan konsumen. Peternak dengan suatu komoditas ternak dapat mengusahakan pengolahan produk ternak asal komoditas ternak lain. Tidak ada yang dapat membatasi produsen untuk mengupayakan bisnis dengan beberapa jenis produk peternakan sehingga peternak membuat produk olahan hasil ternak tersebut dapat mengkombinasikan beberapa lini usaha dalam satu manajemen. Dalam kondisi peternak yang bersifat semi komersil maka manajemen tersebut dapat berupa manajemen keluarga. Hal ini menunjukkan bahwa sapi Pasundan jika dikelola dengan baik, maka akan memberikan keuntungan dengan asumsi peternak memahami pola kewirausahaan dan didukung oleh keberadaan kelompok dengan baik, sehingga penguatan kelompok menjadi optimal.

Manajemen keluarga memiliki administrasi sederhana. Istilah populer untuk usaha dengan manajemen keluarga adalah home industry. Peternak dapat membuat catatan-catatan mengenai usaha mulai dari visi dan misi sederhana, jumlah investasi, pengeluaran dan penerimaan serta cashflow. Meskipun tidak rinci, peternak membuat catatan dari seluruh pengorbanan yang diberikan untuk usaha dan menggunakan opportunity cost untuk input yang diperoleh bukan dari pasar (Romeo Fersi Mongdong, 2015).

Berdasarkan permintaan dari Dinas Peternakan Kabupaten Kuningan untuk melaksanakan pengabdian terkait pendirian 
koperasi peternak sapi Pasundan di Desa Bantar Panjang, maka target pengabdian dan penyuluhan berjudul "Penguatan Kelompok, Koperasi dan Kewirausahaan pada Peternak Sapi Pasundan di Kabupaten Kuningan" ditujukan untuk peternak sapi Pasundan Kelompok Ciciap dan Jaksataruna di Kecamatan Cibingbin Kabupaten Kuningan. Tujuan yang ingin dicapai dari kegiatan ini adalah: 1) Terjadi perubahan pemahaman mengenai penguatan kelompok; 2) Tersosialisasikan pemahaman mengenai pendirian koperasi; Terjadi perubahan pemahaman mengenai kewirausahaan usaha sapi Pasundan.

\section{Metode Pelaksanaan}

Pendekatan yang digunakan terhadap peternak sapi Pasundan adalah pembinaan dan penyuluhan pada kelompok Ciciap dan Jaksataruna di Kecamatan Cibingbin Kabupaten Kuningan Pendekatan awal yang dilakukan adalah melalui identifikasi kelompok peternak sapi Pasundan yang terdapat di desa tersebut termasuk diskusi dengan dinas Peternakan kabupaten Kuningan. Identifikasi ini penting guna melihat permasalahan yang ada disekitar kelompok peternak sapi Pasundan. Pendekatan juga dilakukan kepada tokoh masyarakat yang berpengaruh terhadap usaha peternakan sapi Pasundan. Khalayak sasaran dari penyuluhan ini adalah kelompok peternak Ciciap dan Jaksataruna.

Metode penyuluhan dilakukan kombinasi antara virtual dengan tatap muka langsung. Metode tatap mukalangsung dilakukan kepada ketua kelompok mengenai materi secara keseluruhan, tetapi materi secara virtual disampaikan melalui videu yang kemudian diunggah di youtube. Selanjutnya dilakukan identifikasi narasumber yang sesuai dengan penyuluhan yang diinginkan oleh Dinas Peternakan Kabupaten Kuningan dan pembuatan video bersama. Setelah itu video di upload di aplikasi youtube dengan alasan bahwa aplikasi ini sudah dikenal dengan baik, mudah dan terjangkau oleh masyarakat.

Langkah pertama adalah mengukur dan mengkuantifikasi respon peternak melalui sebuah alat yaitu kuesioner untuk melihat penilaian peserta terhadap keseluruhan materi dan kegiatan pelatihan. Dengan alasan pandemi covid-19, kuesioner untuk peternak dibagikan melalui ketua kelompok dan kemudian dikembalikan kepada tim.

Terlepas dari hambatan tersebut, pendekatan formal dan informal tetap digunakan dalam penyuluhan melalui video agar materi dapat diterima dengan mudah oleh peserta. Teknik pendekatan yang dilakukan meliputi tahapan: observasi awal, diskusi mengenai permasalahan dan solusi, pemaparan dan penyuluhan telah disampaikan dengan baik meskipun petani/peternak tetap menginginkan diskusi lebih lanjut. Metode yang digunakan dalam pelatihan ini adalah:

1. Penyampaian video.

2. Metode penyuluhan dan diskusi diantara pengurus dan anggota kelompok peternak secara langsung melalui peralatan desa (proyektor dan layar).

Model yang diadopsi sebagai kerangka pemecahan masalah berasal dari "The ICA Strategic Planning Model" (Spencer, 1989 dalam Weisbord, 1993). Model ini cukup sederhana dan telah sukses digunakan oleh penduduk desa di Asia dan ratusan perusahaan multinasional. Cara ini merupakan cara yang sesuai dengan budaya di lingkungan Indonesia termasuk sasaran Program PKM ini.

Penyuluhan ini dilaksanakan melalui video online yang diupload di aplikasi youtube dengan link https://youtu.be/tTDGGWJgT-8. Tujuan utama dari kegiatan ini adalah pemberdayaan output produksi yang tidak optimal agar petani dan peternak memperoleh produktivitas usaha yang efektif namun lebih efisien sehingga dapat mengurangi pembiayaan dan atau menambah penerimaan usaha. Ukuran optimal berbeda untuk setiap individu, dengan demikian target capaian senantiasa dikompromikan dengan individu atau petani/peternak yang bersangkutan.

Output dari pelatihan ini adalah peningkatan pengetahuan mengenai penguatan kelompok, koperasi dan kewirausahaan, sedangkan outcome yang diharapkan adalah peningkatan penerimaan 
petani/peternak dengan cara menjual produk lebih efektif dan efisien dengan strategi alternatif untuk meningkatkan kesejahteraan peternak, yakni penjualan ternak melalui koperasi secara rutin sehingga dapat menyediakan daging terbaik untuk stakeholder perhotelan sebagai konsumen dari penjualan ternak.

\section{Hasil dan Pembahasan}

Penguatan pada kelompok Ciciap dan Jaksataruna dilakukan melalui pemberian materi:

1. Menciptakan suatu iklim yang kondusif didalam lingkungan kelompok tani seperti menumbuhkan rasa kepercayaan kepada setiap kelompoknya.

2. Menumbuhkembangkan suatu kreativitas dan prakarsa anggota kelompok untuk memanfaatkan peluang usaha, informasi dan akses suatu permodalan yang tersedia.
3. Membantu memperlancar proses dalam mengidentifikasi suatu masalah serta menyusun dan memecahkan masalah yang dihadapi dalam usahaternaknya.

4. Meningkatkan kemampuan dalam mengetahui potensi pasar dan peluang usaha serta menganalisis potensi yang dimiliki agar bisa mengembangkan usahatani yang lebih besar.

5. Meningkatkan kemampuan dalam menganalisis potensi usaha masingmasing anggota agar menjadi satu unit usaha yang mampu menjamin permintaan pasar.

6. Mendorong dan mengadvokasi agar para peternak mau dan mampu melaksanakan kegiatan simpan pinjam seperti koperasi dalam memfasilitasi pengembangan modal usaha (Prasetyo, Aziz Turindra. 2010)

Tahapan pelaksanaan yang telah direalisasikan di lokasi PKM dan rincian target dari PKM.

Tabel 1. Tahapan realisasi Pelaksanaan PKM

\begin{tabular}{|c|c|c|c|}
\hline \multirow{2}{*}{ No } & \multirow{2}{*}{$\begin{array}{l}\text { Rencana } \\
\text { Kegiatan }\end{array}$} & \multicolumn{2}{|c|}{ Keterlibatan dalam kegiatan } \\
\hline & & Tim PKM & Masyarakat \\
\hline 1. & $\begin{array}{l}\text { Sosialisasi } \\
\text { Kegiatan }\end{array}$ & $\begin{array}{l}\text { Diskusi atau rapat awal mengenai } \\
\text { Pengabdian Kepada Masyarakat di } \\
\text { lokasi tersebut }\end{array}$ & $\begin{array}{l}\text { Diskusi atau rapat awal mengenai } \\
\text { Pengabdian Kepada Masyarakat } \\
\text { di lokasi tersebut }\end{array}$ \\
\hline 2. & $\begin{array}{l}\text { Perumusan } \\
\text { Perencanaan } \\
\text { Penyuluhan }\end{array}$ & $\begin{array}{l}\text { Membagi tugas pokok dan fungsi } \\
\text { setiap dosen, dan masyarakat dalam } \\
\text { pelaksanaan PKM }\end{array}$ & $\begin{array}{l}\text { Membagi tugas diantara target } \\
\text { sasaran (peternak) masyarakat } \\
\text { dalam memfasilitasi kegiatan ini } \\
\text { dan mempersiapkan calon peserta } \\
\text { pelatihan }\end{array}$ \\
\hline 3. & Persiapan & $\begin{array}{l}\text { Mencari narasumber yang tepat, } \\
\text { membuat script materi dan } \\
\text { membuat video materi, ksemudian } \\
\text { menggabungkan video-video } \\
\text { tersebut }\end{array}$ & $\begin{array}{l}\text { Memberikan informasi yang } \\
\text { ditanyakan oleh Tim PKM terkait } \\
\text { pendirian koperasi yang } \\
\text { direncanakan kelompok dengan } \\
\text { Dinas Peternakan Kabupaten } \\
\text { Kuningan }\end{array}$ \\
\hline 4. & $\begin{array}{l}\text { Pelaksanaan } \\
\text { Penyuluhan }\end{array}$ & $\begin{array}{l}\text { Memberikan materi dalam ben-tuk } \\
\text { video,mengajak diskusi, } \\
\text { menstimulasi pertanyaan dan } \\
\text { menjawaban setiap permasalahan }\end{array}$ & $\begin{array}{l}\text { Menerima materi dan berdiskusi } \\
\text { dengan pemberi materi }\end{array}$ \\
\hline
\end{tabular}


Tabel 2. Solusi, Outcome, dan Indikator Capaian PKM

\begin{tabular}{clll}
\hline No. & Solusi & $\begin{array}{l}\text { Outcome yang } \\
\text { diharapkan }\end{array}$ & Indikator Capaian \\
\hline 1 & Penyuluhan & $\begin{array}{l}\text { Peningkatan } \\
\text { pendapatan peternak }\end{array}$ & $\begin{array}{c}\text { Pengetahuan tentang penguatan } \\
\text { kelompok, koperasi dan kewirausahaan }\end{array}$ \\
& & - Ketertarikan kelompok peternak untuk \\
& & menerapkan pengetahuan tersebut \\
& & - Antusias kelompok tani-ternak dalam \\
& & kegiatan pelatihan \\
& & - Keikutsertaan/ keterlibatan khalayak \\
& & sasaran terhadap implementasi koperasi \\
& & peternak sapi pasundan \\
\hline
\end{tabular}

Secara umum ada tiga hal dalam menunjukan kekuataan suatu kelompok yaitu kemampuan kelompok tersebut dalam mecapai tujuan, kemampuan kelompok dalam mempertahanakan

kelompoknya agar tetap kompak, kemampuan kelompok untuk berkembang dan berubah sehingga dapat terus meningkatkan suatu kinerja kelompok. kelompok yang berhasil adalah mempuanyai suatu kualitas dan pola interkasi yang terintegrasi didalam kegiatan diatas ini ( Suharto,2010).

Peternak yang akan membentuk koperasi wajib memahami pengertian, nilai, prinsip, dan syarat-syarat koperasi:

1. Koperasi primer dibentuk dan didirikan oleh sekurang- kurangnya 20 (dua puluh) orang yang mempunyai kegiatan dan kepentingan ekonomi yang sama;

2. Koperasi sekunder dibentuk dan didirikan oleh sekurang- kurangnya 3 (tiga) badan hukum koperasi;

3. Pendiri koperasi primer adalah warga negara Indonesia, cakap secara hukum dan mampu melakukan perbuatan hukum; d. Pendiri koperasi sekunder adalah pengurus koperasi primer yang diberi kuasa dari masing-masing koperasi primer untuk menghadiri rapat pembentukan koperasi sekunder;

4. Usaha yang akan dilaksanakan oleh koperasi layak secara ekonomi, dikelola secara efesien dan mampu memberikan manfaat ekonomi yang nyata bagi anggota;
5. Modal sendiri cukup tersedia untuk mendukung kegiatan usaha yang akan dilaksanakan oleh koperasi;

6. Memiliki tenaga terampil dan mampu untuk mengelola koperasi.

Menurut Zulhartati (2010) dalam Siregar (2020), selain menyediakan suatu usaha untuk pemenuhan konsumsi, koperasi memfasilitasi kegiatan produksi, penyediaan sarana menabung dan meminjam, masyarakat juga membutuhkan suatu lembaga yang membantu produsen dalam memasarkan produknya kepada konsumen. Peranan koperasi sebagai suatu lembaga yang bertugas dalam menyejahterakan serta memajukan perekonomian rakyat telah banyak ditunjukkan di berbagai negara besar di dunia.

Djohan (2013) mengatakan bahwa pengusaha merupakan salah satu pilihan hidup. Entrepreneurship dulu dan sekarang berbeda, dulu wirausaha adalah alternatif terakhir bila tidak mendapat pekerjaan. Kewirausahaan meliputi motivasi dalam berwirausaha, perencanaan usaha hingga pentingnya pemasaran produk olahan ternak terintegrasi, serta pentingnya membangun hubungan dengan pedagang dan atau konsumen secara langsung (As'ad Ajmal, 2019). Terkait dengan materi kewirausahaan maka materi yang diberikan mengenai motivasi dalam berwirausaha dan membuat neraca (catatan) secara sederhana, seperti pengolahan limbah menjadi kompos atau vermikompos dengan harapan menjadi nilai tambah bagi peternak.

Kewirausahaan didefinisikan sebagai proses penciptaan sesuatu yang berbeda 
nilainya dengan menggunakan usaha dan waktu yang diperlukan, memikul resiko finansial, psikologi, dan sosial yang menyertainya serta menerima balas jasa moneter dan kepuasan pribadi. Istilah kewirausahaan dapat diartikan sebagai sikap dan perilaku mandiri yang mampu memadukan unsur cipta, rasa, dan karsa serta karya atau mampu menggabungkan unsur kreativitas, tantangan, kerja keras, dan kepuasan untuk mencapai prestasi maksimal sehingga dapat memberikan nilai tambah maksimal terhadap jasa, barang maupun pelayanan yang dihasilkan dengan mengindahkan sendi-sendi kehidupan masyarakat Sutanto (2002) dalam Krismiwati Muatip (2008).

Tabel 3. Perubahan Pengetahuan dan Sikap Mengenai Penguatan Kelompok, Koperasi dan Kewirausahaan

\begin{tabular}{llcccc}
\hline \multirow{2}{*}{ NO } & \multirow{2}{*}{ U R A I A N } & \multicolumn{4}{c}{ H A S I L } \\
\cline { 3 - 6 } & & \multicolumn{3}{c}{ PRE-TEST } & \multicolumn{2}{c}{ POST-TEST } \\
\cline { 3 - 6 } & Jumlah & $\%$ & Jumlah & $\%$ \\
\hline 1 & Penguatan kelompok & 20 & 60 & 20 & 90 \\
2 & Koperasi & 20 & 45 & 20 & 80 \\
3 & Kewirausahaan & 20 & 60 & 20 & 75 \\
\hline
\end{tabular}

Tabel 3 menunjukkan bahwa terjadi peningkatan pengetahuan sebesar $30 \%$, sementara perubahan pemahaman koperasi terjadi penginkatan pemahaman sebesar 35\%. Peningkatan pemahaman kewirausahaan sebesar 17\%. (Dwiwati dkk. 2016). Peningkatan pengetahuan terjadi karena sebelum diberikan penyuluhan tidak mengetahui secara rinci peran kelompok, mereka menganggap kelompok hanya sebagai ajang kumpul dan silaturachmi partisipasi anggota kelompok belum optimal dimanfaatkan. Peternak sudah mengetahui koperasi, tetapi syarat dan manfaatnya belum dipahami, dengan adanya penyuluhan maka peternak menjadi lebih paham dan memberikan respon yang positif untuk pendirian koperasi. Pemahaman mengenai kewirausahaan juga hanya sebatas usaha pemeliharaan sapi Pasundan, padahal dengan memahami kewirausahaan, peternak dapat membuat usaha sampingan dari usaha sapi Pasundan, seperti pengolahan limbah menjadi kompos dan vermikompos, melalui usaha sapi Pasundan mereka membuat pembukuan secara sederhana, sehingga peternak bisa menghitung biaya produksi serta keuntungan yang diperoleh.

\section{Kesimpulan}

Terjadi peningkatan pengetahuan peternak mengenai penguatan kelompok, koperasi, dan kewirausahaan. Selain itu, peternak, terutama ketua kelompok memberikan respon positif terhadap rencana pembentukan koperasi di wilayahnya. Strategi para peternak selanjutnya adalah merencanakan pendirian koperasi dari dua kelompok tersebut. Saran dari kegiatan PKM ini adalah peternak sebaiknya berusaha untuk menguatkan kelompok dan mencoba mengidentifikasi anggota kelompok yang potensial menjadi pengurus koperasi.

\section{Daftar Pustaka}

As'ad Ajmal. 2019. Pelatihan Motivasi dan Kewirausahaan Bagi Warga Desa. Jurnal Pengabdian Bina Ukhuwah.2(2).

http://jurnal.fe.umi.ac.id/index.php/J PBU/index

Djohan, M. Akbar. 2013. Pengusaha Jadi Pilihan Hidup. Sosialisasi Kebijakan dan Pengembangan Perniagaan dan Kewirausahaan. UPI-Bandung.

Dwiwati D M. Suparta N. Putra I G S A. 2016. Dampak Teknik Penyuluhan Focus Group Discussion (Fgd) Terhadap Perubahan Pengetahuan, Sikap Dan Penerapan Pada Penyuluh Dan Peternak Sapi Bali di Bali. Majalah Ilmiah Peternakan.19(1). 
https://ojs.unud.ac.id/index.php/mip/ article/view/21457.

Krismiwati Muatip, Basita G. Sugihen, Djoko Susanto dan Pang S. Asngari. 2008. Kompetensi Kewirausahaan Peternak Sapi Perah, Kasus Peternak Sapi Perah Di Kabupaten Bandung Jawa Barat. Jurnal Penyuluhan. 4(1). https://journal.ipb.ac.id/index.php/ju pe/article/view/2165

Siregar, Abi Pertiwa. 2020. Kinerja Koperasi Di Indonesia. VIGOR: Jurnal Ilmu Pertanian Tropika dan Subtropika 5 https://ojs.unud.ac.id/index.php/mip/ article/view/21457

Suharto, Edi. 2010. Membangun Masyarakat Memberdayakan Masyarakat "Kajian Strategis Pembangunan Kesejahteraan Sosial dan Pekerjaan Sosial. Bandung : Refika Aditama.

Prasetyo, Aziz Turindra. 2010. Tingkat Partisipasi Masyarakat Desa Miskin Dalam Kegiatan Simpan Pinjam Khusus untuk Perempuan di Kecamatan Bendosari Kabupaten Sukoharjo. Surakarta : UNS Press.

Wardani. Oeng Anwarudin. 2018. Peran Penyuluh Terhadap Penguatan Kelompok Tani dan Regenerasi Petani Di Kabupaten Bogor Jawa Barat. Journal Tabaro. 2(1). http://ojs.unanda.ac.id/index.php/jtas/ article/view/113/94

Weisbord, Marvin Ross. 1993. Discovering Common Ground: How Future Search Conferences Bring People Together to Achieve Breakthrough Innovation, Empowerment, Shared Vision, and Collaborative Action. Berrett-Koehler Publishers, Inc. United States of America.

Romeo Fersi Mongdong, Jenny Morasa, Heince Wokas. 2015. Analisis Differential Cost Dan Opportunity Cost Dalam Pengambilan Keputusan Membeli Atau Memproduksi Sendiri Pada Industri Rumah Panggung Woloan. Jurnal Riset Akuntansi. https://ejournal.unsrat.ac.id/index.ph $\mathrm{p} / \mathrm{gc} /$ article/view/8370
Zulhartati, Sri. 2010. Peranan Koperasi dalam Perekonomian Indonesia. Jurnal Guru Membangun. 25(3). https://jurnal.untan.ac.id/index.php/jg $\mathrm{mm} /$ article/view/233/231. 